\title{
The Significance of Macronutrients in Alternate Bearing 'Nadorcott' Mandarin Trees
}

\author{
Ockert P.J. Stander ${ }^{1}$ \\ Citrus Research International (Pty) Ltd., Department of Horticultural \\ Science, University of Stellenbosch, Stellenbosch, South Africa
}

Graham H. Barry

XLnT Citrus, Cape Town, South Africa

Paul J.R. Cronjé

Citrus Research International (Pty) Ltd., Department of Horticultural Science, University of Stellenbosch, Stellenbosch, South Africa

Additional index words. Citrus reticulata, flowering, fruit load, nutrition, vegetative shoot development

\begin{abstract}
The significance of macronutrients nitrogen (N), phosphorus (P), potassium $(\mathrm{K})$, calcium (Ca), and magnesium (Mg) in leaves was studied in relation with their possible roles in alternate bearing of 'Nadorcott' mandarin (Citrus reticulata) trees over a period of three seasons. Fruit load ("on," a heavy fruit load, vs. "off," a light fruit load) affected the leaf macronutrient concentrations, and the amount of macronutrients removed through the harvest of fruit, i.e., the crop removal factor $\left(\mathrm{g}^{\circ} \mathrm{kg}^{-1}\right)$, was consistent in both seasons. The crop removal factors were higher for each macronutrient in "off" trees-harvest of $1 \mathrm{~kg}$ fruit removed $\approx 2.3 \mathrm{~g} \cdot \mathrm{kg}^{-1} \mathrm{~N}, 0.3 \mathrm{~g} \cdot \mathrm{kg}^{-1} \mathrm{P}, 3.1 \mathrm{~g} \cdot \mathrm{kg}^{-1} \mathrm{~K}$, $1.0 \mathrm{~g} \cdot \mathrm{kg}^{-1} \mathrm{Ca}$, and $0.4 \mathrm{~g} \cdot \mathrm{kg}^{-1} \mathrm{Mg}$, compared with $1.3 \mathrm{~g} \cdot \mathrm{kg}^{-1} \mathrm{~N}, 0.2 \mathrm{~g} \cdot \mathrm{kg}^{-1} \mathrm{P}, 1.7 \mathrm{~g} \cdot \mathrm{kg}^{-1} \mathrm{~K}$, $0.6 \mathrm{~g} \cdot \mathrm{kg}^{-1} \mathrm{Ca}$, and $0.2 \mathrm{~g} \cdot \mathrm{kg}^{-1} \mathrm{Mg}$ in "on" trees. Fruit load per tree (kg/tree) of 84, 110, and $52 \mathrm{~kg} /$ tree in "on" trees, however, removed $\approx 217 \mathrm{~g} /$ tree $\mathrm{N}, 28 \mathrm{~g} /$ tree P, $296 \mathrm{~g} /$ tree K, $100 \mathrm{~g} /$ tree Ca, and $35 \mathrm{~g} /$ tree $\mathrm{Mg}$, which was 1.5-6 times more than that of fruit loads of 14, 71 , and $16 \mathrm{~kg} /$ tree in "off" trees. In "off" trees, N, P, and K, and in "on" trees, Ca accumulated in leaves to between $20 \%$ and $30 \%$ higher concentrations in season 1 , but the higher macronutrient status did not manifest in or consistently correlate with intensity of summer vegetative shoot development in the current season, or intensity of flowering in the next season, the two main determinants of fruit load in 'Nadorcott' mandarin. Apart from some anomalies, the concentrations of macronutrients in leaves were unaffected by de-fruiting and foliar spray applications of $\mathrm{N}$ and $\mathrm{K}$ to "on" trees, and showed no consistent relationship with treatment effects on parameters of vegetative shoot development and flowering. Leaf macronutrients in alternate bearing ' $N$ adorcott' mandarin trees, fertilized according to grower standard practice, are not related to differences in flowering and vegetative shoot development, and appear to be a consequence of fruit load and not a determinant thereof.
\end{abstract}

Alternate bearing is a problematic phenomenon that occurs in certain fruit and nut trees. It is characterized by trees flowering profusely and producing an excess amount of fruit in one season, called an "on" season,

\footnotetext{
Received for publication 8 June 2018. Accepted for publication 28 Aug. 2018.

We thank Doepie Van Zyl, Kallie Junius, and C.P. Mouton for providing access to orchards in De Doorns, Riviersonderend, and Citrusdal, South Africa; to Dome Citrus, Indigo Fruit Farming, Sitrusrand Boerdery, Suiderland Plase, Sundays River Citrus Company, and Unifrutti for providing leaf analyses and fruit load data of commercial 'Nadorcott' mandarin orchards; and to Daan Nel for assistance with statistical analysis.

This work forms part of a Ph.D. study that was funded by the South African Citrus Growers Association and Citrus Research International (Pty) Ltd.

${ }^{1}$ Corresponding author. E-mail: jakkie@sun.ac.za.
}

Koo et al., 1984). For those purposes, fertilizer recommendations in South African citrus production make use of a routine leaf analysis that is based on a combination of leaf mineral nutrient norms that were developed for sweet orange (Citrus sinensis) cultivars in the United States (Chapman, 1949; Embleton et al., 1973; Koo et al., 1984) and for sweet orange, grapefruit (Citrus paradisi), and lemon (Citrus limon) cultivars in South Africa (Du Plessis, 1977; Du Plessis and Koen, 1992; Du Plessis et al., 1992). These leaf mineral nutrient norms are used to assess the tree nutritional status, to replace the nutrients that were removed by fruit or lost to the environment in the current season, and to achieve a target fruit load in the following season (Jones and Embleton, 1969). Currently, there are no definitive leaf mineral nutrient norms for mandarin (C. reticulata) to guide production of cultivars such as 'Nadorcott' in South Africa. As part of a wider study on alternate bearing in 'Nadorcott' mandarin, it was shown that fruit load in "on" "Nadorcott' mandarin trees inhibits summer vegetative shoot development, which manifests in poor flowering and an "off" crop (Stander et al., 2018). However, it is not clear if current fertilizer practices and the concentration of macronutrients in leaves affect this mechanism of the alternate bearing cycle of 'Nadorcott' mandarin.

To address this question, seasonal changes in concentrations of macronutrients, namely, $\mathrm{N}, \mathrm{P}, \mathrm{K}, \mathrm{Ca}$, and $\mathrm{Mg}$, were determined in leaves of "on" and "off" "Nadorcott' mandarin trees and correlated with vegetative shoot flush, flowering, and fruit load. In addition, leaf macronutrient concentration and phenological responses were measured in reaction to source/sink manipulations at different phenological stages, as well as in response to autumn foliar applications of $\mathrm{N}$ and $\mathrm{K}$. To compare results from tree experiments to a representative commercial alternate bearing scenario, a survey was carried out in 15 commercial 'Nadorcott' mandarin orchards in South Africa showing an alternate bearing pattern, to determine whether there is a relationship between the concentrations of macronutrients in leaves and change in fruit load from one season to another.

\section{Materials and Methods} fruit and the "off" crop typically consists large and unappealing fruit (Galliani et al., 1975; Hield and Hilgeman, 1969; Monselise and Goldschmidt, 1982; Moss et al., 1974). Alternate bearing leads to costly challenges in the management of harvesting, transport, packing, and marketing of citrus fruit, as well as compromises on the quality of fruit and consistency of production practices in the orchard, such as pruning, fruit thinning, irrigation, and fertilization (Galliani et al., 1975; Hield and Hilgeman, 1969; Moss et al., 1974; Stander and Cronjé, 2016).

In commercial citriculture, fertilizers are applied annually to optimize the growth of citrus trees and to maximize the volume and quality of fruit yield (Embleton et al., 1978;

\section{Plant material and experimental site}

Ten- to 15-year-old 'Nadorcott' mandarin trees budded onto 'Carrizo' citrange $(C$. sinensis $\times$ Poncirus trifoliata) rootstock and grown under commercial conditions were selected within orchards with a history of alternate bearing in De Doorns (lat. $33^{\circ} 51^{\prime} \mathrm{S}$, long. $19^{\circ} 52^{\prime} \mathrm{E}$ ) for Expt. 1, in Citrusdal (lat. $32^{\circ} 81^{\prime} \mathrm{S}$, long. $19^{\circ} 01^{\prime} \mathrm{E}$ ) for Expt. 2, and in Riviersonderend (lat. $34^{\circ} 13^{\prime} \mathrm{S}$, long. $19^{\circ} 89^{\prime} \mathrm{E}$ ) for Expt. 3. All the experimental sites are located in the Western Cape Province of South Africa. The Western Cape forms part of one of five climatically diverse citrus-growing regions in Southern Africa 
and experiences Mediterranean-type climatic conditions: summer typically occurs from December to February; autumn from March to May; winter from June to August; and spring from September to November. The region receives an annual rainfall of between 400 and $650 \mathrm{~mm}$ and the majority occurs from the end of autumn to the end of winter (May-August).

The orchard in De Doorns was used in the main experiment and was cultivated, pruned, and sprayed according to recommended agricultural practices: trees were spaced at $5 \times$ $2 \mathrm{~m}(1000$ trees/ha) and planted in a sandy soil with $\mathrm{pH}_{(\mathrm{KCl})}$ 4.4. Trees were watered using a drip irrigation system with four emitters per tree, and total water supply was $\approx 4000 \mathrm{~L}$ per tree per annum. All trees received consistent and standard fertilizer applications with the rate of application $\left(\mathrm{kg} \cdot \mathrm{ha}^{-1}\right)$ based on annual leaf mineral nutrient analysis and a target fruit yield of between 60 and 70 ton $\cdot \mathrm{ha}^{-1}$. For N, a leaf concentration between 22 and $26 \mathrm{mg} \cdot \mathrm{g}^{-1}$ leaf dry weight (DW) was considered optimum by the citrus grower. Total annual $\mathrm{N}$ application amounted to $240 \mathrm{~kg} \cdot \mathrm{ha}^{-1}$, of which $25 \%$ was applied as foliar applications, $20 \%$ as soil applications, and 55\% was dissolved in the irrigation solution, i.e., fertigation, and split uniformly into eight applications from September to April. The rates of annual $\mathrm{P}$ and $\mathrm{K}$ applications were targeted to maintain optimum leaf $\mathrm{P}$ and $\mathrm{K}$ concentrations of between 1.1 and $1.5 \mathrm{mg} \cdot \mathrm{g}^{-1}$ leaf DW for $\mathrm{P}$ and between 9 and $16 \mathrm{mg} \cdot \mathrm{g}^{-1}$ leaf $\mathrm{DW}$ for $\mathrm{K}$. The total annual $\mathrm{P}$ and $\mathrm{K}$ applications amounted to 12 $\mathrm{kg} \cdot \mathrm{ha}^{-1} \mathrm{P}$ and $265 \mathrm{~kg} \cdot \mathrm{ha}^{-1} \mathrm{~K}$, with the majority applied via fertigation and a small fraction applied by foliar sprays. The $\mathrm{Ca}$ and $\mathrm{Mg}$ applications were targeted to maintain optimum leaf concentrations of between 35 and $50 \mathrm{mg} \cdot \mathrm{g}^{-1}$ leaf DW for $\mathrm{Ca}$, and 3 and 5.5 $\mathrm{mg} \cdot \mathrm{g}^{-1}$ leaf DW for $\mathrm{Mg}$, and supplied as 60 and $22 \mathrm{~kg} \cdot \mathrm{ha}^{-1}$, respectively. Calcium was applied via fertigation from August to November, whereas $\mathrm{Mg}$ was applied as one foliar spray in August, plus increasing portions from September to March via fertigation.

\section{Treatments and experimental design}

Expt. 1. In this experiment, the pattern of concentrations of the five major macronutrients in leaves in "on" and "off" trees were followed as independent variables over a period of two seasons and the data were used in correlation analyses with selected determinants of flowering and fruit load as dependent variables. The trees that were selected were representative of heavy- or light-fruiting trees and subsequently included as singletree replications of "on" and "off" treatments in a completely randomized design $(n=10)$. Most of the trees in the orchard bore similar fruit yields, but for the purpose of this experiment, individual trees that showed an opposite and natural alternate bearing trend were selected before harvest in season 1 (Aug. 2014). Data representing the results of leaf macronutrient analysis, as well as the correlations between leaf macronutrients and flowering, vegetative shoot development, and fruit load made use of only eight of the respective "on" and "off" treatment replications $(n=8)$.

Expt. 2. To validate the interpretation of the results from Expt. 1 on the concentrations of macronutrients in leaves and the relationship with phenological responses, leaf N, P, $\mathrm{K}, \mathrm{Ca}$, and $\mathrm{Mg}$ concentrations, as well as vegetative shoot flush and flowering responses to complete fruit removal of heavyfruiting or "on" trees were determined at two phenological stages, namely, during vegetative shoot development in Summer (Jan. 2016), and during flower induction in $\mathrm{Au}-$ tumn (Apr. 2016). The "on" cycles of 12 trees were desynchronized by removing all fruit of six heavy-fruiting trees in Jan. 2016, for the Summer treatment, and six heavyfruiting trees in Apr. 2016, for the Winter treatment. The experiment was set up in a completely randomized design, using whole trees as treatment replications $(n=6)$.

Expt. 3. Mineral nutrient foliar sprays were applied to heavy-fruiting or "on" trees $\approx 210 \mathrm{~d}$ after full bloom on 11 May 2016, between 8:00 and 10:00 HR. The foliar sprays consisted of the following treatments that were set up in a randomized complete block design $(n=6)$ : 1$)$ an untreated control; 2) $\mathrm{N}$ [10 g. $\mathrm{L}^{-1}$ low biuret urea (Sasol, Sandton, South Africa) containing $\left.460 \mathrm{~g} \cdot \mathrm{kg}^{-1} \mathrm{~N}\right]$; and 3) $\mathrm{K}\left[30 \mathrm{~g} \cdot \mathrm{L}^{-1}\right.$ fully soluble, crystalline formulation of potassium nitrate $\left(\mathrm{KNO}_{3}\right)$ (Sasol, Sandton, South Africa)]. Foliar sprays were applied until the point of runoff at a rate of $\approx 4 \mathrm{~L}$ spray solution per tree, using a backpack mist-blow sprayer [Stihl SR430; Andreas Stihl (Pty), Ltd., Pietermaritzburg, South Africa] set at droplet size 2 (1-fine droplet size, 5-coarse droplet size). No surfactant was used in the foliar spray mixture. To avoid drift between different treatments, buffer trees were left untreated between treated and control trees in the same row, as well as buffer rows between treated rows. The trees were selected for uniformity in tree condition based on a dark green leaf color. All trees were similar in canopy volume with a height of between $\approx 3.5$ $4.0 \mathrm{~m}$ and an across-row width of 2.5 $3.5 \mathrm{~m}$. The trees had a trunk circumference of $\approx 35 \mathrm{~cm}$ as measured above the bud union, and a uniform and evenly distributed fruit load.

\section{Data collection}

Flowering, fruit set and vegetative shoot development. In Expt. 1, the number of flowers per tree was estimated by counting the number of flowers within the limits of a $0.5 \times 0.5 \times 0.5 \mathrm{~m}$ frame during full bloom in October. The tree canopy was divided into an eastern and western sector and an upper- and lower-half. A flower count was performed in each of these four respective quadrants per tree. The total number of flowers was estimated by extrapolating the mean number of flowers per frame to the total tree volume. The canopy volume $\left[V\left(\mathrm{~m}^{3}\right)\right]$ was calculated according to the following formula (Burger et al., 1970):

$$
V=r^{2}(\pi h-1.046 r)
$$

where $r=$ canopy radius and $h=$ height of the fruit bearing canopy.

The same trees were used in both seasons. The same procedure was used to estimate the number of new vegetative shoots after cessation of periods of vegetative shoot flushes in spring (November), summer (February), and autumn (April)

The phenological pattern of shoots in "on" and "off" trees was followed by randomly selecting five vegetative ("off") and five reproductive ("on") shoots from each tree during full bloom in season 1 (Oct. 2014). All shoots were $\approx 12$ months of age and had triangular internodes, a length of $\approx 15 \mathrm{~cm}$ and were located on the outside of the tree canopy at a height of $\approx 1.5 \mathrm{~m}$ above the orchard floor. On each shoot, the number of nodes, the number of vegetative shoots, and total number of flowers were counted. At the end of summer (February) and start of autumn (March), the numbers of persistent fruit and new vegetative shoots that developed during the subsequent vegetative shoot flushes were recorded for each shoot, and return bloom and vegetative response were determined on the same shoots during the subsequent season.

Fruit yield. In all the experiments, commercial fruit harvest commenced in mid-July, once fruit quality indices complied with specifications established by fruit export markets. Harvest was completed by the end of August. To determine the total fruit yield of the treatments, all fruit were harvested separately from individual trees on the same day, before the start of commercial harvest. A sample of 100 fruit was randomly collected from each tree replication and the transverse diameter (in $\mathrm{mm}$ ) of each fruit was measured using an electronic fruit size measuring caliper (CD-6" C; Mitutoyo Corp, Tokyo, Japan). Each fruit was assigned to a fruit size category of which the average fruit weight was determined and fruit size distribution from each treatment replication was extrapolated for the total number of fruit per tree.

Leaf and fruit sampling for mineral nutrient analysis. The leaf sampling protocol for the analysis of mineral nutrients is different for the major citrus-producing countries. In California (Chapman, 1968; Embleton et al., 1973), Florida (Koo and Sites, 1956; Koo et al., 1984; Smith, 1966), and Australia (Jorgensen and Price, 1978), leaves are sampled from 4- to 10-month-old, nonfruiting, and purely vegetative shoots. Citrus growers in Brazil (Quaggio et al., 1996), Israel (Raveh, 2013), and South Africa (Du Plessis, 1977; Du Plessis and Koen, 1992; Du Plessis et al., 1992) sample leaves from 4- to 6month-old fruiting shoots. The use of fruiting shoots though, may not be wholly reliable as the characteristics of fruit on different trees and shoots might be different and cause variation in leaf nutrient analysis results. Also, results from mineral nutrient analyses 
of leaves sampled from fruiting shoots cannot necessarily be used to predict what will happen in the future, as it is not guaranteed that fruit will remain on the tree during the period between sampling and timing of the next fertilizer application. More importantly, nonfruiting and purely vegetative shoots are those on which the majority of the next season's flowers and fruit will develop from (Verreynne and Lovatt, 2009), which is of direct interest in this experiment because results from such leaf mineral nutrient analyses could be used in validating predictions of flowering and fruit load.

In the present study, only mature leaves were sampled from the third to fifth position on fully hardened, nonfruiting, and purely vegetative shoots. All shoots had triangular internodes, a length of $\approx 15 \mathrm{~cm}$, and were located on the outside of the tree canopy at a height of $\approx 1.5 \mathrm{~m}$ above the orchard floor. In Expt. 1, the spring leaf samples were collected in September, from vegetative shoots that developed during the previous season's vegetative shoot flushes; the summer leaf samples were collected in December, from vegetative shoots that developed during the current season's spring vegetative shoot flush, and autumn and winter leaf samples were collected in March and June, from vegetative shoots that developed during the current season's summer vegetative shoot flush (Fig. 1). In Expt. 2, leaf samples were collected from vegetative shoots that developed during the current season's summer vegetative shoot flush, starting on the day of treatment in January and continued at monthly intervals until commercial harvest commenced in July. In Expt. 3, leaf samples were collected on the day of treatment, and again 2 weeks thereafter.

One leaf sample consisted of eight leaves that were collected from each of four shoots from each treatment replication, between 0800 and $1000 \mathrm{HR}$ on each sampling date. After sampling, the leaves were kept cool and washed with distilled water, before being frozen at $-80{ }^{\circ} \mathrm{C}$ and freeze-dried (Christ Beta 1-8 LD Freeze Dryer; Martin Christ Gefriertrocknungsanlagen $\mathrm{GmbH}$, Osterode am Harz, Germany). The leaves were ground to a fine powder with an analytical grinder (Yellow line, A10; IKA-Werke, Staufen, Germany) and stored at $-80^{\circ} \mathrm{C}$ until analysis.

In Expt. 1, fruit samples were collected from different canopy positions at the time of commercial harvest to determine the macronutrient concentration of fruit (rind and pulp combined) from each of three distinct fruit size categories. For each sampled fruit, the transverse diameter was measured with an electronic caliper, and the mass $(\mathrm{g})$ of each fruit was determined with an electronic scale (W22 Series; UWE Co., Hsin Tien, Taiwan). Fruit were subsequently assigned to a fruit size category, namely, small $(\approx 50 \mathrm{~mm}$ and $71 \mathrm{~g})$, medium $(\approx 63 \mathrm{~mm}$ and $131 \mathrm{~g})$, and large $(\approx 76 \mathrm{~mm}$ and $203 \mathrm{~g})$. From each fruit size category, six fruit samples consisting of 12 fruit were analyzed for macronutrient concentrations.

The concentrations of the macronutrients in the fruit tissue (rind and pulp combined) were used to calculate the total mass of the respective macronutrients removed by the total fruit loads in "on" and "off" trees by using the total fruit yield in $\mathrm{kg}$ fruit per tree and fruit size distribution data for each of the treatment replications.

Analysis of macronutrient concentrations. Macronutrient analyses in leaf and fruit samples were conducted by an accredited commercial chemical and microbiology analytical laboratory [Bemlab (Pty) Ltd., Strand, South Africa] according to published protocols (Hou and Jones, 2000). Briefly, $1 \mathrm{~g}$ of fruit or dried leaf tissue was ashed at $800{ }^{\circ} \mathrm{C}$ and made up to a volume of $50 \mathrm{~mL}$ with a 50:50 hydrochloric acid (50\%) solution for extraction through filter paper. The $\mathrm{P}, \mathrm{K}, \mathrm{Ca}$, and $\mathrm{Mg}$ concentrations were analyzed using inductively coupled plasma-emission spectroscopy (Varian PRX-OEX; Varian Inc., Palo Alto, CA) against suitable standards and after a nitric-hydrochloric total acid digestion step. For analysis of total N, $0.15 \mathrm{~g}$ of each sample was combusted at $850{ }^{\circ} \mathrm{C}$ and analyzed using a LECO $\mathrm{N}$ analyzer (LECO FP528 Nitrogen analyzer; LECO cooperation, St. Joseph, MI) by thermal conductivity. The concentrations of the macronutrients in the leaf and fruit were expressed as $\mathrm{mg} \cdot \mathrm{g}^{-1}$ leaf DW or $\mathrm{mg} \cdot \mathrm{g}^{-1}$ fruit fresh weight.

Commercial fruit load and leaf macronutrient data. To compare the results from the tree experiments with representative commercial alternate bearing scenarios, a survey was carried out in 15 commercial 'Nadorcott' mandarin orchards in South Africa showing an alternate bearing pattern. Fruit load and leaf nutrient analyses of at least three consecutive seasons were collected between 2013 and 2017. Each orchard covered an area of at least two hectares and showed an alternate bearing pattern across three consecutive harvests [an alternate bearing index $(I)$ higher than 0.15 (Monselise and Goldschmidt, 1982)]. The alternate bearing index of each orchard was calculated using the following formula (Gur et al., 1969):

$$
I=\frac{1}{(n-1)}\left[\frac{(a 2-a 1)}{(a 2+a 1)}+\frac{(a 3-a 2)}{(a 3+a 2)}+\ldots\right],
$$

where $n=$ number of seasons and $a=$ fruit yield (as $\mathrm{kg} /$ tree) in the corresponding seasons, with the difference in yield between two seasons expressed as an absolute value.

The total area of orchards used in the survey was $\approx 65$ ha. The orchards are located in Clanwilliam (lat. $32^{\circ} 33^{\prime} \mathrm{S}$, long. $18^{\circ} 83^{\prime} \mathrm{E}$ ), De Doorns, and Graafwater (lat. $32^{\circ} 16^{\prime} \mathrm{S}$, long. $\left.18^{\circ} 59^{\prime} \mathrm{E}\right)$ in the Western Cape Province; in Kirkwood (lat. $33^{\circ} 46^{\prime} \mathrm{S}$, long. $25^{\circ} 56^{\prime} \mathrm{E}$ ) and Addo (lat. $33^{\circ} 48^{\prime} \mathrm{S}$, long. $\left.25^{\circ} 56^{\prime} \mathrm{E}\right)$ in the Eastern Cape Province; and in Mbombela (lat. $25^{\circ} 40^{\prime} \mathrm{S}$, long. $31^{\circ} 01^{\prime} \mathrm{E}$ ) in Mpumalanga Province. The orchards were cultivated according to good agricultural practices, and the commercial harvest of

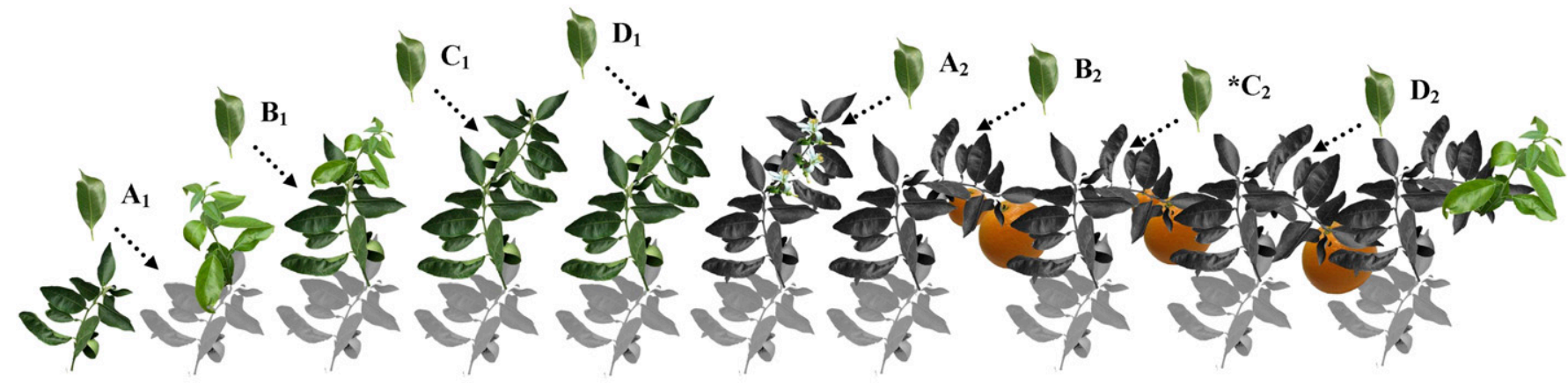

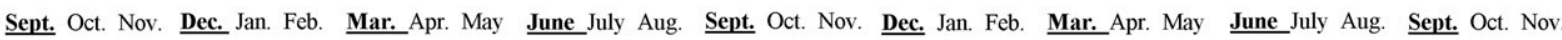

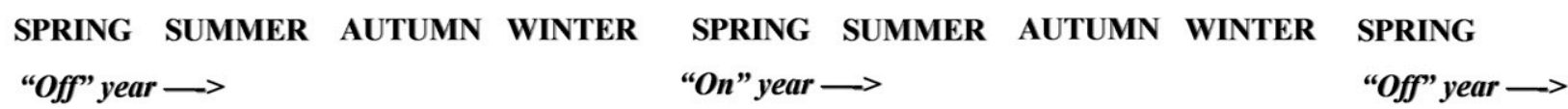

Fig. 1. Spring leaf samples for macronutrient analyses in alternate bearing 'Nadorcott' mandarin trees were collected in September $\left(\mathbf{A}_{\mathbf{1}}\right.$ and $\left.\mathbf{A}_{\mathbf{2}}\right)$, from vegetative shoots that developed during the previous season's vegetative shoot flushes; the summer leaf samples were collected in December $\left(\mathbf{B}_{\mathbf{1}}\right.$ and $\left.\mathbf{B}_{\mathbf{2}}\right)$, from vegetative shoots that developed during the current season's spring vegetative shoot flush, and autumn and winter leaf samples were collected in March $\left[\mathbf{C}_{\mathbf{1}}\right.$ and $\mathbf{C}_{\mathbf{2}}(*=$ also commercial time of sampling)] and June $\left(\mathbf{D}_{\mathbf{1}}\right.$ and $\left.\mathbf{D}_{2}\right)$, from vegetative shoots that developed during the current season's summer vegetative shoot flush. 
orchards commenced in June and finished by the end of August. Fruit load per tree $(\mathrm{kg} /$ tree) for each orchard was calculated using the fruit yield (ton.ha ${ }^{-1}$ ) of each orchard for each commercial harvest, the tree spacing (trees/ha), and the orchard area (ha).

Leaf mineral nutrient analyses were conducted in March. The sampling of leaves was carried out according to the South African citrus industry standard, namely, leaves were sampled from 4- to 6-month-old fruiting shoots (Du Plessis, 1977; Du Plessis and Koen, 1992; Du Plessis et al., 1992).

\section{Statistical analysis}

STATISTICA data analysis software version 14 (Dell, Inc. 2017, Round Rock, TX) was used to analyze the data. Analysis of variance (ANOVA) or repeated measures ANOVA was performed when responses were repeated on the same respondent. Mean separations were carried out using Fisher's least significant difference test where applicable, at $P \leq 0.05$. The relationships between the concentrations of individual macronutrients and vegetative shoot development, flowering and fruit load, respectively, are indicated by Spearman's coefficient of correlation $(r)$. The fruit load of commercial orchards in each season was tested for normality distribution. The relationship between fruit load in the current season and fruit load in the following season was analyzed by regression analysis; as well as the relationship between fruit load and the concentrations of the various macronutrients in leaves. The strength of the relationships is indicated by Spearman's $r$. The median and mean values for fruit load of all commercial orchards were determined using descriptive statistics. The average value for the median and the mean of the fruit loads $(47 \mathrm{~kg} /$ tree $)$ were used to classify fruit load of trees in every orchard as "on" (a fruit load $>47 \mathrm{~kg}$ / tree) or "off" (a fruit load $<47 \mathrm{~kg} /$ tree). These categories were used to do frequency counts and calculate the probability of "on" or "off" trees to experience an "on" or "off" year in the following season. The categorization of fruit load data were used to perform an ANOVA for the leaf macronutrient concentrations of "off" or "on" trees in commercial orchards.

\section{Results and Discussion}

The amount of macronutrients removed through the harvest of fruit, i.e., the crop removal factor $\left(\mathrm{g} \cdot \mathrm{kg}^{-1}\right)$, was higher for each macronutrient in "off" trees compared with "on" trees; the harvest of $1 \mathrm{~kg}$ fruit per tree removed $\approx 2.3 \mathrm{~g} \cdot \mathrm{kg}^{-1} \mathrm{~N}, 0.3 \mathrm{~g} \cdot \mathrm{kg}^{-1} \mathrm{P}, 3.1$ $\mathrm{g} \cdot \mathrm{kg}^{-1} \mathrm{~K}, 1.0 \mathrm{~g} \cdot \mathrm{kg}^{-1} \mathrm{Ca}$, and $0.4 \mathrm{~g} \cdot \mathrm{kg}^{-1} \mathrm{Mg}$ in "off" trees vs. $1.3 \mathrm{~g} \cdot \mathrm{kg}^{-1} \mathrm{~N}, 0.2 \mathrm{~g} \cdot \mathrm{kg}^{-1} \mathrm{P}, 1.7$ g. $\mathrm{kg}^{-1} \mathrm{~K}, 0.6 \mathrm{~g} \cdot \mathrm{kg}^{-1} \mathrm{Ca}$, and $0.2 \mathrm{~g} \cdot \mathrm{kg}^{-1} \mathrm{Mg}$ in "on" trees. Total fruit load ( $\mathrm{kg} /$ tree), though, was 6-fold higher in "on" trees in season 1, almost 2-fold higher in "on" trees in season 2 , and almost 3 -fold higher in "on" trees in season $3(P<0.01)$ (Table 1$)$. In season 1 , season 2 , and season 3 , fruit loads of 84,110 , and $52 \mathrm{~kg} /$ tree in "on" trees (Table 1) removed on average $217 \mathrm{~g} /$ tree $\mathrm{N}, 28 \mathrm{~g} /$ tree $\mathrm{P}$, $296 \mathrm{~g} /$ tree $\mathrm{K}, 100 \mathrm{~g} /$ tree $\mathrm{Ca}$ and $35 \mathrm{~g} /$ tree $\mathrm{Mg}$, which were two to seven times more than that removed by fruit loads of 14,71 , and $16 \mathrm{~kg}$ / tree in "off" trees $(P<0.01)$ (Table 2$)$. This is in agreement with studies in 'Michal', 'Murcott', and 'Wilking' mandarins, where up to $32 \%, 44 \%$, and $58 \%$ more $\mathrm{N}, \mathrm{P}$, and $\mathrm{K}$ were removed by the harvesting of heavyfruiting trees, compared with harvesting of light-fruiting trees (Golomb and Goldschmidt, 1987; Monselise et al., 1983; Smith, 1976). In the present study, "off" trees, on the other hand, sprouted two to three times more new vegetative shoots than "on" trees (Tables 3 and 4). Similar to what has been reported in other mandarin trees (Golomb and Goldschmidt, 1987; Monselise et al., 1983; Smith, 1976), N, P, and K accumulated in leaves of "off" trees, and Ca in leaves of "on" trees to between $20 \%$ and $30 \%$ higher concentrations in season $1(P<0.01)$ (Fig. 2).

Despite the differences in macronutrient concentrations between "on" and "off"

Table 1. Fruit yield, return bloom, and vegetative response over 3 years of 10-year-old alternate bearing 'Nadorcott' mandarin trees used in Expt. 1 .

\begin{tabular}{|c|c|c|c|c|c|c|}
\hline \multirow{3}{*}{$\begin{array}{l}\text { Tree fruiting } \\
\text { status }\end{array}$} & \multirow{3}{*}{$\begin{array}{l}\begin{array}{c}\text { Fruit yield in } \\
\text { current yr }\end{array} \\
\text { (kg/tree })\end{array}$} & \multirow[b]{2}{*}{$\begin{array}{l}\text { Fruit per tree } \\
\text { in current yr }\end{array}$} & \multicolumn{4}{|c|}{ Return bloom and vegetative response in the following yr } \\
\hline & & & Flowers & $\begin{array}{c}\text { New spring } \\
\text { vegetative shoots }\end{array}$ & $\begin{array}{c}\text { New summer } \\
\text { vegetative shoots }\end{array}$ & $\begin{array}{c}\text { Total new } \\
\text { vegetative shoots }\end{array}$ \\
\hline & & \multicolumn{5}{|c|}{ (no./tree) } \\
\hline "Off" tree & $14 \mathrm{~b}$ & $126 \mathrm{~b}$ & $51,097 \mathrm{a}$ & $163 \mathrm{~b}$ & $144 \mathrm{~b}$ & $306 \mathrm{~b}$ \\
\hline "On" tree & $84 \mathrm{a}$ & $918 \mathrm{a}$ & $30,034 \mathrm{~b}$ & $493 \mathrm{a}$ & 369 a & $863 \mathrm{a}$ \\
\hline$P$ value & $<0.01$ & $<0.01$ & $<0.01$ & $<0.01$ & $<0.01$ & $<0.01$ \\
\hline \multicolumn{7}{|l|}{ Season 2} \\
\hline$P$ value & $<0.01$ & $<0.01$ & $<0.01$ & $<0.01$ & $<0.01$ & $<0.01$ \\
\hline \multicolumn{7}{|l|}{ Season 3} \\
\hline "Off" tree & $16 \mathrm{~b}$ & $144 \mathrm{~b}$ & & & & \\
\hline "On" tree & $52 \mathrm{a}$ & $621 \mathrm{a}$ & & & & \\
\hline$P$ value & $<0.01$ & $<0.01$ & & & & \\
\hline
\end{tabular}

Different letters in the same column within a given season denote significant differences between values $(P<0.05$; Fisher's least significant difference test; $n=10)$.

Table 2. The total amount nitrogen $(\mathrm{N})$, phosphorus $(\mathrm{P})$, potassium $(\mathrm{K})$, calcium $(\mathrm{Ca})$, and magnesium $(\mathrm{Mg})$ removed by the total number of fruit in "on" and "off" 'Nadorcott' mandarin trees at harvest, respectively, over three seasons in Expt. 1.

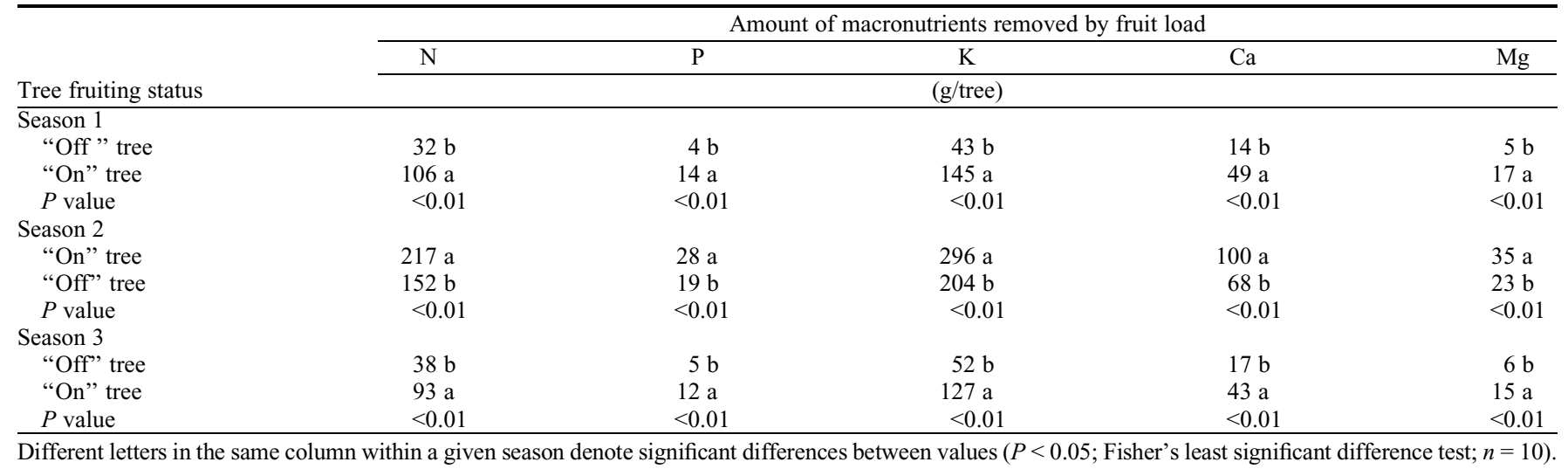


Table 3. The effect of tree fruit load ("on" or "off") on vegetative shoot growth, flowering, and fruit set in alternate bearing 'Nadorcott' mandarin trees, over two seasons in Expt. 1.

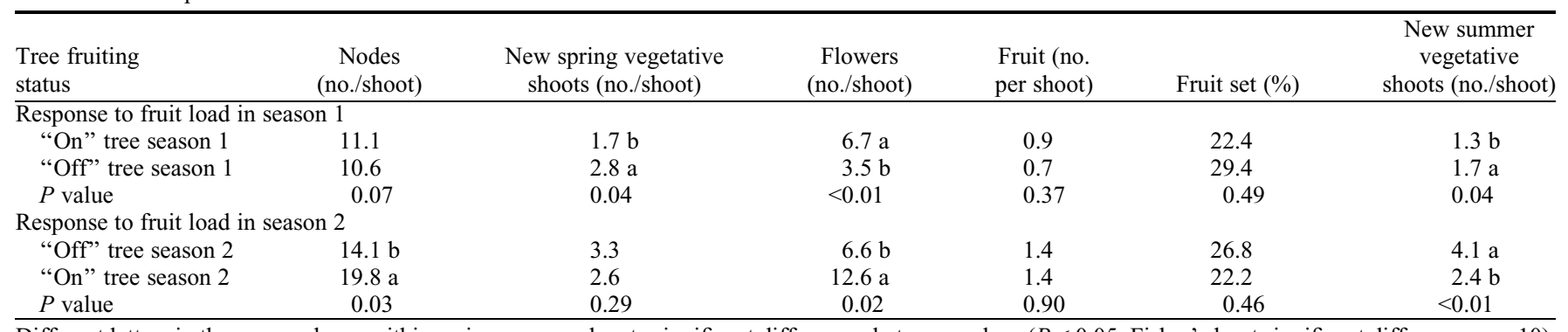

Different letters in the same column within a given season denote significant differences between values $(P<0.05$; Fisher's least significant difference, $n=10)$.

Table 4. The relationship between measurements of tree phenological events and the concentrations of leaf nitrogen $(\mathrm{N})$, phosphorus $(\mathrm{P})$, potassium $(\mathrm{K})$, calcium (Ca), and magnesium (Mg) in alternate bearing 'Nadorcott' mandarin trees in seasons 1 and 2 of Expt. 1.

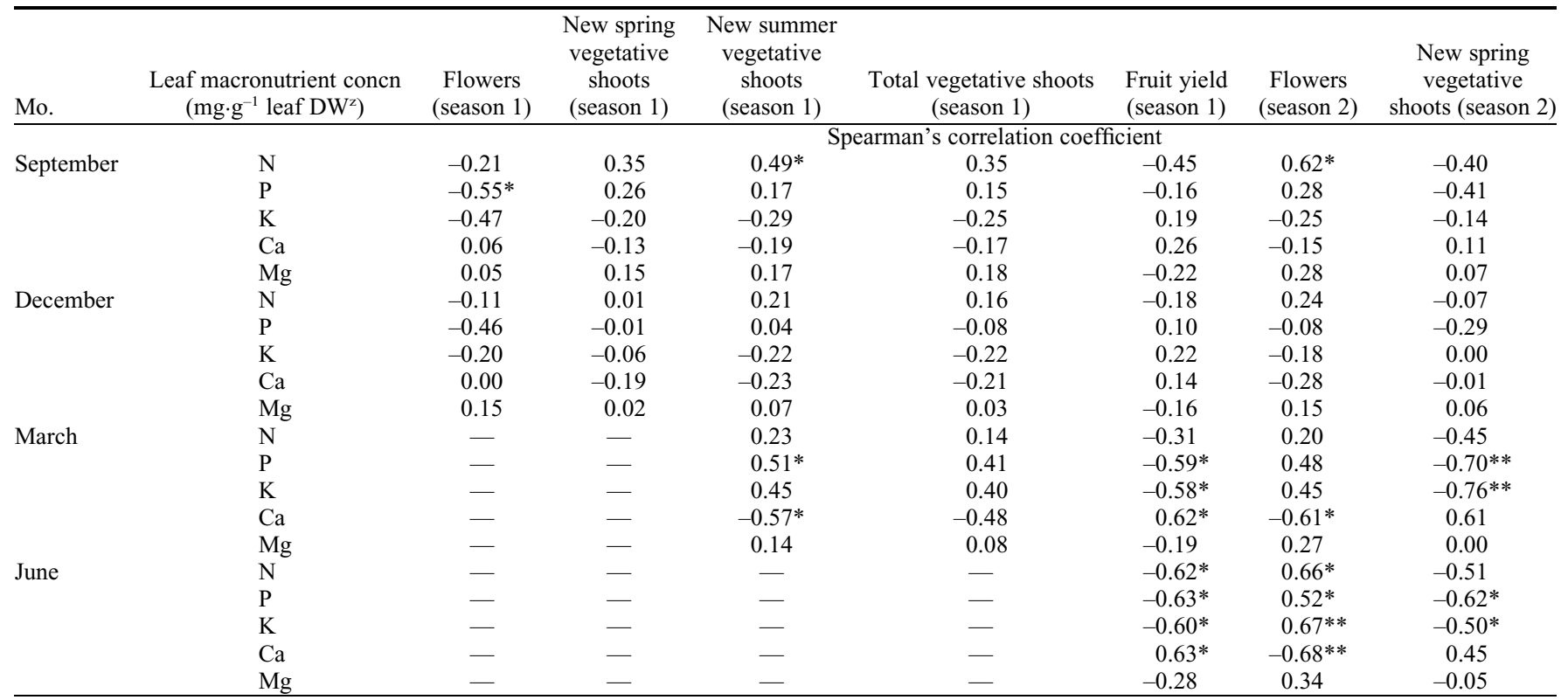

${ }^{\mathrm{z}}$ Dry weight.

The strength of the relationship is indicated by Spearman's correlation coefficient. * and ** indicate significance at $P<0.05$ and $P<0.01$, respectively.

'Nadorcott' mandarin trees, the concentrations of macronutrients in leaves showed no consistent relationship with vegetative shoot development, or with flowering and fruit load in the subsequent season, in any of the treatments, or in commercial alternate bearing 'Nadorcott' mandarin orchards, over three seasons. Nitrogen concentration in leaves during spring was positively but weakly correlated with summer vegetative shoot development in both seasons; spring of season $1(r=0.49, P=0.05)$ and spring of season $2(r=0.51, P=0.049)$ (Tables 4 and 5). In season 1 , the concentrations of $\mathrm{N}$ and $\mathrm{P}$ in leaves during winter (June) correlated positively with flowering during spring of season 2 (N: $r=0.66, P=0.01 ; \mathrm{P}: r=0.52$, $P=0.04)$, but in the following season, leaf $\mathrm{N}$ concentration had a strong negative correlation with flowering $(r=-0.79, P<0.01)$, whereas leaf $\mathrm{P}$ concentration showed no correlation with flowering $(r=0.10, P=$ 0.75 ) (Tables 4 and 5).

Leaf $\mathrm{Ca}$ and $\mathrm{Mg}$ concentrations during spring and summer were not related to total new vegetative shoots in season $1(\mathrm{Ca}$ : spring: $r=-0.17, P=0.52$ and summer: $r=$
$-0.21, P=0.44 ; \mathrm{Mg}$ : spring: $r=0.18, P=$ 0.51 and summer: $r=0.03, P=0.92$ ), nor in season 2 (Ca: spring: $r=0.33, P=0.21$ and summer: $r=0.22, P=0.40$; $\mathrm{Mg}$ : spring: $r=$ $-0.18, P=0.54$ and summer: $r=-0.05, P=$ 0.86) (Tables 4 and 5). Leaf Ca concentration during winter correlated negatively with return bloom in season $1(r=-0.68, P<$ 0.01 ), and leaf $\mathrm{Ca}$ and $\mathrm{Mg}$ concentrations during winter were not correlated to return bloom in season $2(\mathrm{Ca}: r=-0.12, P=0.90$ and Mg: $r=-0.15, P=0.84$ ) (Tables 4 and 5).

During flower induction, leaf $\mathrm{K}$ concentration was positively correlated with return bloom in both seasons (season 1: $r=0.67, P<$ 0.01 ; season 2: $r=0.65, P<0.01$ ) (Tables 4 and 5), but foliar spray treatments of "on" trees with $\mathrm{N}$ and $\mathrm{K}$ during flower induction at the end of season 1 , to validate these positive correlations, failed to improve flowering (data not shown). De-fruiting experiments substantiated the lack of a relationship between leaf macronutrient concentrations and vegetative shoot development, or flowering and fruit load. Apart from some anomalies, e.g., a lower leaf $\mathrm{N}$ concentration of summer de-fruited trees compared with "on" trees in February (21.3 vs. $22.9 \mathrm{mg} \cdot \mathrm{g}^{-1}$ leaf $\mathrm{DW} ; P=0.02)$, there were no differences in the concentrations of any of the leaf macronutrients that were induced by the de-fruiting treatments in "on" trees (Table 6). Those that differed were not related to any vegetative or flowering responses (Table 7). A defruiting treatment of "on" trees in summer, for example, increased vegetative shoot development almost 9-fold compared with the control or "on" trees (Table 7), but the treatment had no effect on leaf macronutrient concentrations (Table 6). Similarly, there were no differences in the concentrations of $\mathrm{N}, \mathrm{P}$, and $\mathrm{K}$ in leaves in any of the treatments following autumn de-fruiting in April, but "off" trees and "on" trees that were de-fruited in summer sprouted more flowers compared with "on" trees, and "on" trees that were de-fruited in autumn (Tables 7 and 8).

The lack of a relationship between the concentration of macronutrients in leaves and the subsequent flowering and fruit load responses in alternate bearing 'Nadorcott' mandarin trees suggests that macronutrient concentration in leaves are not the decisive 


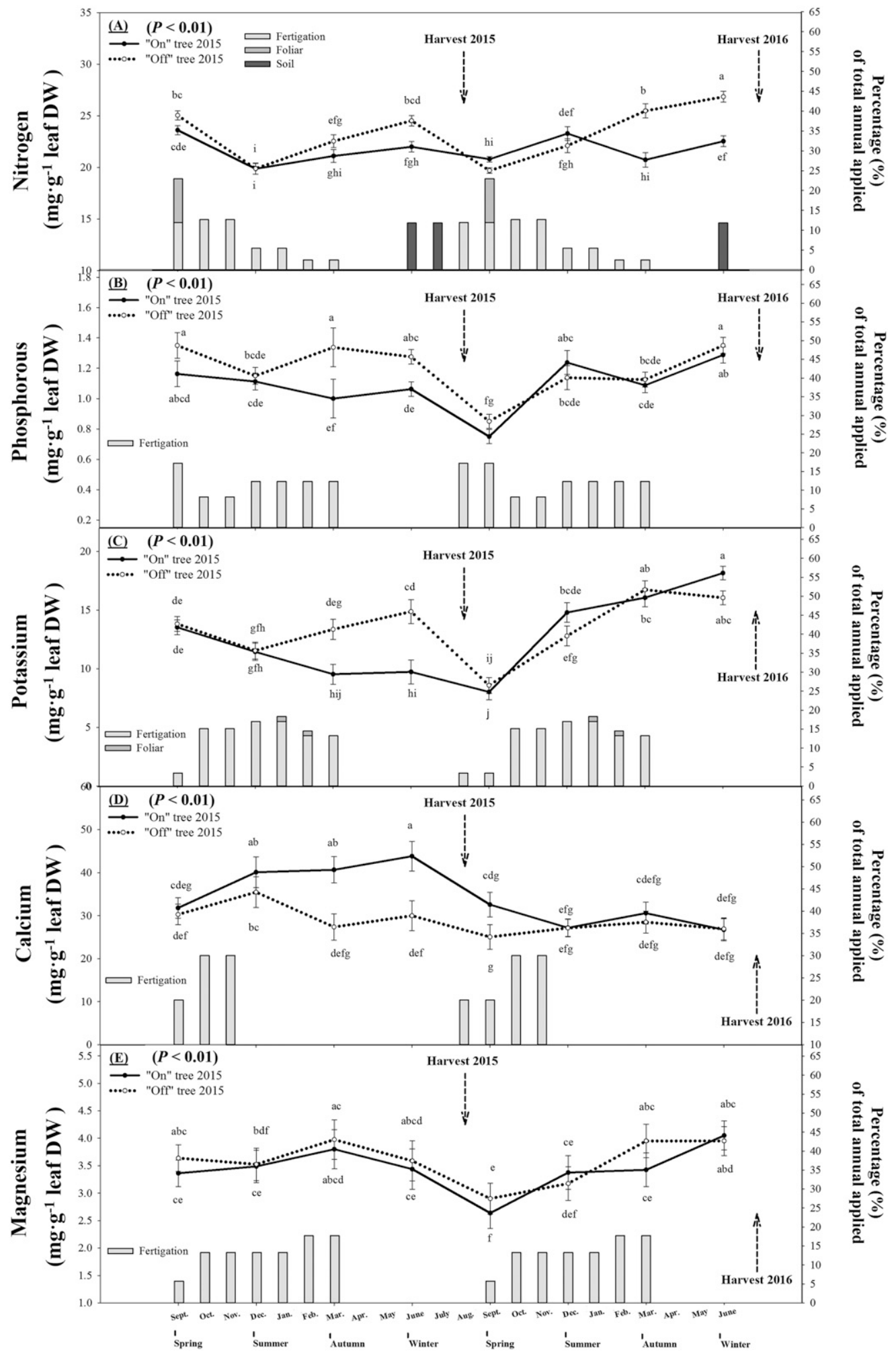

Fig. 2. The concentrations of leaf nitrogen $(\mathbf{A})$, phosphorus $(\mathbf{B})$, potassium $(\mathbf{C})$, calcium $(\mathbf{D})$, and magnesium $(\mathbf{E})$ determined at 3-month intervals over two seasons in alternate bearing 'Nadorcott' mandarin trees. The line graph corresponds to the left $Y$-axis and represents the concentration of the mineral elements in the leaf expressed as mg.g $\mathrm{g}^{-1}$ leaf dry weight (DW), whereas the bar graph corresponds to the right $Y$-axis and represents the rate and distribution of the annual nutrient application as a percentage of the total annual application. The arrows indicate the time of harvest. Bars denote standard error of the mean and different letters indicate significant differences between values over time $(P<0.05$; Fisher's least significant difference test; $n=8)$.

factor of vegetative shoot development, flowering, and fruit load of adequately fertilized and alternate bearing 'Nadorcott' mandarin trees. To support a maximum fruit yield of between 60 and 70 ton $\cdot \mathrm{ha}^{-1}$ in mandarins,
Raveh (2013) recommended that the optimum concentrations of the macronutrients in mandarin leaves should be between 20 and 24 $\mathrm{mg} \cdot \mathrm{g}^{-1}$ leaf DW for N, 0.9 and $1.2 \mathrm{mg} \cdot \mathrm{g}^{-1}$ leaf DW for P, 5.5 and $6.9 \mathrm{mg} \cdot \mathrm{g}^{-1}$ leaf DW for K, and 1.9 and $2.6 \mathrm{mg} \cdot \mathrm{g}^{-1}$ leaf DW for Mg. Alva et al. (2006) reported that optimum N, P, and $\mathrm{K}$ concentrations in 4-6-month-old spring flush leaves of mandarins are 26-30 $\mathrm{mg} \cdot \mathrm{g}^{-1}$ leaf DW for $\mathrm{N}, 0.8-2.4 \mathrm{mg} \cdot \mathrm{g}^{-1}$ leaf 
Table 5. The relationship between measurements of tree phenological events and the concentrations of leaf nitrogen $(\mathrm{N})$, phosphorus $(\mathrm{P})$, potassium $(\mathrm{K})$, calcium (Ca), and magnesium $(\mathrm{Mg})$ in alternate bearing 'Nadorcott' mandarin trees in seasons 2 and 3 of Expt. 1.

\begin{tabular}{|c|c|c|c|c|c|c|c|c|}
\hline \multirow[b]{2}{*}{ Mo. } & \multirow{2}{*}{$\begin{array}{l}\text { Leaf macronutrient concn } \\
\text { (mg.g }{ }^{-1} \text { leaf dry weight) }\end{array}$} & $\begin{array}{c}\text { Flowers } \\
\text { (season 2) } \\
\end{array}$ & $\begin{array}{l}\text { New spring } \\
\text { vegetative } \\
\text { shoots } \\
\text { (season 2) }\end{array}$ & $\begin{array}{l}\text { New summer } \\
\text { vegetative } \\
\text { shoots } \\
\text { (season 2) }\end{array}$ & $\begin{array}{c}\text { Total } \\
\text { vegetative } \\
\text { shoots } \\
(\text { season } 2)\end{array}$ & $\begin{array}{l}\text { Fruit yield } \\
\text { (season 2) }\end{array}$ & $\begin{array}{c}\text { Flowers } \\
\text { (season 3) }\end{array}$ & $\begin{array}{c}\text { New spring } \\
\text { vegetative } \\
\text { shoots } \\
\text { (season } 3 \text { ) }\end{array}$ \\
\hline & & \multicolumn{7}{|c|}{ Spearman's correlation coefficient } \\
\hline \multirow[t]{5}{*}{ September } & $\mathrm{N}$ & $-0.51^{*}$ & 0.32 & $0.51^{*}$ & 0.37 & -0.44 & $0.51 *$ & -0.35 \\
\hline & $\mathrm{P}$ & 0.23 & $-0.50 *$ & -0.46 & -0.49 & 0.30 & 0.10 & -0.20 \\
\hline & $\mathrm{K}$ & 0.01 & -0.17 & -0.22 & -0.21 & 0.12 & 0.01 & 0.10 \\
\hline & $\mathrm{Ca}$ & $-0.51 *$ & 0.25 & 0.34 & 0.33 & $-0.51 *$ & -0.25 & 0.25 \\
\hline & $\mathrm{Mg}$ & 0.24 & -0.06 & -0.19 & -0.17 & 0.37 & 0.15 & 0.27 \\
\hline \multirow[t]{5}{*}{ December } & $\mathrm{N}$ & -0.25 & -0.10 & 0.15 & 0.02 & -0.09 & 0.04 & 0.02 \\
\hline & $\mathrm{P}$ & -0.49 & -0.12 & 0.01 & -0.04 & -0.32 & 0.02 & -0.24 \\
\hline & $\mathrm{K}$ & $-0.57^{*}$ & 0.05 & 0.15 & 0.11 & -0.32 & -0.08 & 0.12 \\
\hline & $\mathrm{Ca}$ & 0.00 & 0.06 & 0.23 & 0.22 & -0.02 & 0.08 & -0.11 \\
\hline & $\mathrm{Mg}$ & 0.21 & -0.01 & 0.00 & -0.05 & 0.35 & 0.05 & 0.06 \\
\hline \multirow[t]{5}{*}{ March } & $\mathrm{N}$ & - & - & $-0.80 * *$ & $-0.68 * *$ & $0.78 * *$ & $-0.69 * *$ & $0.65^{*}$ \\
\hline & $\mathrm{P}$ & - & - & -0.35 & -0.40 & 0.05 & 0.20 & -0.15 \\
\hline & $\mathrm{K}$ & - & - & -0.09 & -0.31 & 0.08 & 0.18 & -0.20 \\
\hline & $\mathrm{Ca}$ & - & - & 0.16 & 0.17 & 0.24 & -0.12 & 0.20 \\
\hline & $\mathrm{Mg}$ & - & - & -0.25 & -0.26 & 0.37 & -0.21 & 0.11 \\
\hline \multirow[t]{5}{*}{ June } & $\mathrm{N}$ & - & - & - & - & $0.79 * *$ & $-0.79 * *$ & $0.69^{*}$ \\
\hline & $\mathrm{P}$ & - & - & - & - & -0.07 & 0.10 & -0.05 \\
\hline & $\mathrm{K}$ & - & - & - & - & $-0.50 *$ & $0.65^{*}$ & $-0.51^{*}$ \\
\hline & $\mathrm{Ca}$ & - & - & - & - & -0.03 & -0.12 & 0.14 \\
\hline & $\mathrm{Mg}$ & - & - & - & - & 0.12 & -0.15 & 0.21 \\
\hline
\end{tabular}

The strength of the relationship is indicated by Spearman's correlation coefficient. * and ** indicate significance at $P<0.05$ and $P<0.01$, respectively.

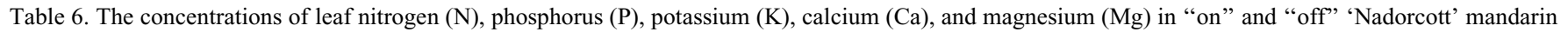
trees, and in response to de-fruiting of "on" trees applied in the Summer (January) and Autumn (April) of 2016 in Expt. 2.

\begin{tabular}{|c|c|c|c|c|c|c|}
\hline Treatments & January & February & March & April & May & June \\
\hline & \multicolumn{6}{|c|}{$\mathrm{N}$ mg.g ${ }^{-1}$ leaf dry weight } \\
\hline "On" trees & 22.2 & $22.9 \mathrm{a}$ & 23.7 & 24.8 & 26.4 & 23.9 \\
\hline "Off" trees & 22.9 & $22.8 \mathrm{a}$ & 23.8 & 25.1 & 26.0 & 22.5 \\
\hline "On" trees de-fruited in January & 22.2 & $21.3 \mathrm{~b}$ & 21.4 & 23.0 & 23.6 & 22.3 \\
\hline "On" trees de-fruited in April & 22.6 & $23.0 \mathrm{a}$ & 23.8 & 24.3 & 25.5 & 22.4 \\
\hline \multirow[t]{2}{*}{$P$ value } & 0.53 & 0.02 & 0.13 & 0.23 & 0.33 & 0.58 \\
\hline & \multicolumn{6}{|c|}{ P mg.g ${ }^{-1}$ leaf dry weight } \\
\hline "On" trees & 1.08 & 1.16 & $0.98^{\circ}$ & 1.18 & 1.26 & 1.20 \\
\hline "Off" trees & 1.24 & 1.16 & 1.14 & 1.30 & 1.34 & 1.14 \\
\hline "On" trees de-fruited in January & 1.10 & 1.02 & 0.94 & 1.20 & 1.18 & 1.16 \\
\hline "On" trees de-fruited April & 1.14 & 1.14 & 1.02 & 1.22 & 1.34 & 1.20 \\
\hline \multirow[t]{2}{*}{$P$ value } & 0.11 & 0.07 & 0.33 & 0.48 & 0.27 & 0.76 \\
\hline & \multicolumn{6}{|c|}{$\mathrm{K}$ mg.g ${ }^{-1}$ leaf dry weight } \\
\hline "On" trees & $12.4 \mathrm{~b}$ & 11.4 & 10.5 & $10.9 \mathrm{~b}$ & 11.0 & 7.6 \\
\hline "Off" trees & $15.0 \mathrm{a}$ & 13.1 & 12.5 & $13.7 \mathrm{a}$ & 13.3 & 9.8 \\
\hline "On" trees de-fruited January & $12.0 \mathrm{~b}$ & 9.5 & 9.5 & $11.1 \mathrm{~b}$ & 10.7 & 8.9 \\
\hline "On" trees de-fruited April & $12.2 \mathrm{~b}$ & 11.6 & 10.3 & $10.3 \mathrm{~b}$ & 11.9 & 8.7 \\
\hline \multirow[t]{2}{*}{$P$ value } & $<0.01$ & 0.10 & 0.20 & 0.02 & 0.39 & 0.26 \\
\hline & \multicolumn{6}{|c|}{ Ca mg.g ${ }^{-1}$ leaf dry weight } \\
\hline "On" trees & 31.8 & 29.5 & $28.8 \mathrm{ab}$ & $31.9 \mathrm{a}$ & $33.4 \mathrm{ab}$ & 33.2 \\
\hline "Off" trees & 27.0 & 27.5 & $24.5 \mathrm{~b}$ & $22.5 \mathrm{~b}$ & $27.0 \mathrm{~b}$ & 30.3 \\
\hline "On" trees de-fruited January & 35.9 & 34.5 & $36.1 \mathrm{a}$ & $30.6 \mathrm{a}$ & $38.8 \mathrm{a}$ & 36.2 \\
\hline "On" trees de-fruited April & 35.5 & 35.7 & $33.4 \mathrm{a}$ & $32.6 \mathrm{a}$ & $34.1 \mathrm{ab}$ & 30.7 \\
\hline \multirow[t]{2}{*}{$P$ value } & 0.06 & 0.20 & 0.02 & 0.02 & 0.03 & 0.32 \\
\hline & \multicolumn{6}{|c|}{ Mg mg.g ${ }^{-1}$ leaf dry weight } \\
\hline "On" trees & 4.1 & 3.6 & 3.2 & 3.6 & 4.0 & $3.6 \mathrm{ab}$ \\
\hline "Off" trees & 3.6 & 3.4 & 3.4 & 3.1 & 3.6 & $3.2 \mathrm{bc}$ \\
\hline "On" trees de-fruited January & 4.0 & 4.2 & 4.0 & 3.7 & 4.0 & $4.1 \mathrm{a}$ \\
\hline "On" trees de-fruited April & 3.8 & 3.6 & 3.5 & 3.8 & 3.5 & $2.8 \mathrm{c}$ \\
\hline$P$ value & 0.22 & 0.15 & 0.26 & 0.08 & 0.53 & 0.01 \\
\hline
\end{tabular}

DW for $\mathrm{P}$, and $15-18 \mathrm{mg} \cdot \mathrm{g}^{-1}$ leaf DW for $\mathrm{K}$. South African citrus growers use leaf macronutrient norms of between 20 and $28 \mathrm{mg} \cdot \mathrm{g}^{-1}$ leaf DW for N, 1.1 and $1.6 \mathrm{mg} \cdot \mathrm{g}^{-1}$ leaf DW for P, 9 and $16 \mathrm{mg} \cdot \mathrm{g}^{-1}$ leaf DW for K, 35 and $55 \mathrm{mg} \cdot \mathrm{g}^{-1}$ leaf DW for $\mathrm{Ca}$, and 3.3 and 5.5 $\mathrm{mg} \cdot \mathrm{g}^{-1}$ leaf $\mathrm{DW}$ for $\mathrm{Mg}$ (Du Plessis and Koen, 1992). Throughout all the experiments in this study, however, "on" or "off" trees with leaf $\mathrm{N}, \mathrm{P}, \mathrm{K}, \mathrm{Ca}$, and $\mathrm{Mg}$ concentrations within these ranges did not consistently flower or sprout new vegetative shoots, despite "on" and "off" trees receiving the same amount of fertilizer (Tables 2 and 3; Fig. 2). Very few new vegetative shoots developed from parent shoots in "on" trees compared with "off" trees, and from season 2 to season 3 , flower intensity was lower and fruit load decreased from $110 \mathrm{~kg} /$ tree to 16 $\mathrm{kg} /$ tree, whereas the concentrations of leaf $\mathrm{N}, \mathrm{P}, \mathrm{K}, \mathrm{Ca}$, and $\mathrm{Mg}$ in "on" trees during summer, before harvest, at harvest, and during flowering were between 21 and $24 \mathrm{mg} \cdot \mathrm{g}^{-1}$ leaf DW for N, 0.8 and $1.3 \mathrm{mg} \cdot \mathrm{g}^{-1}$ leaf DW for P, 10 and $15 \mathrm{mg} \cdot \mathrm{g}^{-1}$ leaf DW for K, 26.0 $45.0 \mathrm{mg} \cdot \mathrm{g}^{-1}$ leaf $\mathrm{DW}$ for $\mathrm{Ca}$, and $2.8-3.4$ $\mathrm{mg} \cdot \mathrm{g}^{-1}$ leaf $\mathrm{DW}$ for $\mathrm{Mg}$, and within the 
industry norm (Tables 2 and 3; Fig. 2). The same inconsistent relationships between the change in fruit load from one season to another, and that of the leaf macronutrient concentrations occurred in "off" trees, as well as in the 15 commercial 'Nadorcott' mandarin orchards, across three seasons.

In commercial 'Nadorcott' mandarin orchards, fruit load in the current season correlated negatively with fruit load in the following season $(r=-0.55, P<0.01)$. There was a moderately strong $(68 \%)$ probability for orchards with a light fruit load ("off"), i.e., orchards with an average tree fruit load lower than the mean and median of all commercial fruit load data, namely, $47 \mathrm{~kg} /$ tree in the current year, to have a heavy fruit load ("on"), i.e., a fruit load higher than 47 $\mathrm{kg} /$ tree in the following year. For orchards in an "on" season to experience a subsequent "off" season, the probability was $62 \%$. The analyses, together with the calculated alternate bearing index (Table 8), confirmed that all the selected commercial orchards were in a definitive alternate bearing cycle. In concurrence with results from experiments using single-tree replications (Fig. 2), K concentration was greater in leaves of trees in "off" commercial orchards ( $10.5 \mathrm{vs.} 9.4 \mathrm{mg} \cdot \mathrm{g}^{-1}$ leaf DW; $P=0.04)$ and Ca concentration was greater in leaves of trees in "on" commercial orchards (42.7 vs. $34.8 \mathrm{mg} \cdot \mathrm{g}^{-1}$ leaf DW; $P<$ 0.01 ) (Table 9). Despite this, no relationships were found between fruit load in the current season and the concentration of any macronutrients in the standard leaf analyses of commercial orchards in March, or between the concentration of any of the macronutrients from the current season and fruit load of the next (Table 1). There were no correlations between fruit load and concentrations of macronutrients in leaves in the current season (except for $\mathrm{Ca})(\mathrm{N}: r=-0.23, P=0.06$; $\mathrm{P}: r=$ $0.01, P=0.94 ; \mathrm{K}: r=-0.12, P=0.32$; $\mathrm{Ca}: r=$ $0.48, P<0.01 ; \mathrm{Mg}: r=-0.07, P=0.58$ ); or between leaf $\mathrm{N}, \mathrm{P}, \mathrm{K}, \mathrm{Ca}$, and $\mathrm{Mg}$ concentrations in the current season, and fruit load in the next $(\mathrm{N}: r=-0.18, P=0.15 ; \mathrm{P}: r=0.02$, $P=0.15 ; \mathrm{K}: r=0.30, P=0.20$; Ca: $r=0.08$, $P=0.49$; Mg: $r=-0.19, P=0.13$ ).

Tree nutrient status as measured by foliar analysis may influence fruit load via fruit size or an alteration of fruit set potential in mandarin cultivars such as 'Nules Clementine' mandarin and sweet orange cultivars such as 'Valencia' and 'Washington Navel' (Lovatt, 1999, 2013). However, the factor limiting fruit load and causing an "off" season in 'Nadorcott' mandarin trees was not poor fruit set but a lack of vegetative shoot development and flowers (Stander et al., 2018). In fact, percentage of fruit set in "off" 'Nadorcott' mandarin trees was similar to "on" trees, but because flower number was almost 2-fold lower, it did not manifest in a larger fruit yield compared with heavy-flowering "on" trees (Tables 1 and 3).

Table 7. Vegetative shoot development and flowering in "on" and "off" 'Nadorcott' mandarin trees, and "on" trees in reaction to de-fruiting in the Summer (January) and Autumn (April) of 2016 in Expt. 2.

\begin{tabular}{|c|c|c|}
\hline & $\begin{array}{l}\text { New summer vegetative } \\
\text { shoots (season } 1)\end{array}$ & $\begin{array}{c}\text { Spring floral } \\
\text { intensity (season 2) }\end{array}$ \\
\hline Tree fruiting status (season 1) & (no./tree) & (no./tree) \\
\hline "On" trees & $9 \mathrm{c}$ & $18,942 \mathrm{c}$ \\
\hline "Off" trees & $34 \mathrm{~b}$ & $43,110 \mathrm{a}$ \\
\hline "On" trees de-fruited in January & $79 \mathrm{a}$ & $32,324 \mathrm{~b}$ \\
\hline "On" trees de-fruited in April & $11 \mathrm{c}$ & $22,991 \mathrm{c}$ \\
\hline$P$ value & $<0.01$ & $<0.01$ \\
\hline
\end{tabular}

Different letters in the same column denote significant differences between values $(P<0.05$; Fisher's least significant difference test; $n=6$ ).

These results question the pertinence of current nutritional guidelines or leaf mineral nutrient norms that are used for 'Nadorcott' mandarin orchards in an alternate bearing cycle in South Africa, where the purpose of fertilization should be different during an "on" vs. an "off" season in terms of manipulating vegetative shoot flush, flowering, and fruit load (Stander et al., 2018). Similar to what has been reported for avocado (Persea americana) (Campisi-Pinto et al., 2017), it could be possible that leaf analysis is not sensitive enough to detect changes in macronutrient status of 'Nadorcott' mandarin trees, or differences in fertilization rates that may affect fruit load or result in the manifestation of alternate bearing. For example, in other evergreen fruit trees such as avocado, coffee (Coffea arabica), and olive (Olea europaea), organs such as flowers, petioles of leaves, and stems of flowers and fruit are alternative tree organs from which nutrient analyses provide valuable supplemental information to leaf nutrient analyses (Campisi-Pinto et al., 2017; Castillo-Gonzalez et al., 2000; Khelil et al., 2010; Martinez et al., 2003; Razeto and Salgado, 2004). Indeed, studies on mineral nutrients and alternate bearing in other mandarin cultivars, e.g., 'Kinnow' (Mirsoleimani et al., 2014) and 'Michal', 'Wilking', and 'Murcott' (Monselise et al., 1983), have shown that the effects of fruit load in the current season on bud responses in the following season are also closely related to the nutrient concentration in stems. The relationship between macronutrient concentration in stems or buds, and vegetative shoot development and flowering should, therefore, be investigated in 'Nadorcott' mandarin as a mean to predict flowering and fruit load and to fertilize accordingly.

Although these results on the relationship between leaf macronutrients and alternate bearing are in contrast to some of those obtained in deciduous fruit and nut trees, e.g., apple (Malus domestica) (Neilsen et al., 1990) and pistachio (Pistachia vera) (Rosecrance et al., 1998), they are consistent with results

Table 8. The summary of a survey carried out in 15 commercial alternate bearing 'Nadorcott' mandarin orchards in South Africa. Fruit load per tree (kg/tree) for each orchard was calculated using the fruit yield (ton $\cdot \mathrm{ha}^{-1}$ ) of each orchard for each commercial harvest, the tree spacing (trees/ha), and the orchard area (ha).

\begin{tabular}{|c|c|c|c|c|c|c|c|c|c|c|c|c|c|c|c|c|c|c|c|}
\hline \multirow{2}{*}{$\begin{array}{l}\text { Orchard } \\
\text { no. }\end{array}$} & & & & \multirow{2}{*}{$\frac{\mathrm{AB} \text { index }}{(I)^{\mathrm{z}}}$} & \multicolumn{15}{|c|}{ Leaf macronutrient concn ( $\mathrm{mg} \cdot \mathrm{g}^{-1}$ leaf dry weight) } \\
\hline & \multicolumn{3}{|c|}{ Fruit load (kg/tree) } & & \multicolumn{3}{|c|}{$\mathrm{N}$} & \multicolumn{3}{|c|}{$\mathrm{P}$} & \multicolumn{3}{|c|}{$\mathrm{K}$} & \multicolumn{3}{|c|}{$\mathrm{Ca}$} & \multicolumn{3}{|c|}{$\mathrm{Mg}$} \\
\hline 1 & 18 & 66 & 15 & 0.60 & 24.7 & 27.0 & 19.8 & 1.3 & 1.2 & 1.2 & 10.4 & 13.6 & 7.1 & 44.6 & 33.5 & 30.9 & 5.0 & 5.6 & 6.4 \\
\hline 3 & 18 & 61 & 20 & 0.52 & 25.7 & 24.1 & 20.7 & 1.3 & 1.3 & 1.2 & 8.8 & 9.3 & 7.2 & 48.4 & 37.2 & 29.0 & 4.8 & 4.8 & 5.6 \\
\hline 4 & 49 & 103 & 42 & 0.39 & 22.9 & 21.9 & 22.6 & 1.5 & 1.3 & 2.0 & 9.0 & 8.1 & 15.9 & 43.5 & 48.9 & 47.2 & 4.6 & 4.0 & 3.9 \\
\hline 5 & 49 & 91 & 34 & 0.38 & 24.1 & 24.6 & 25.1 & 1.3 & 1.5 & 1.0 & 17.4 & 15.9 & 15.5 & 19.7 & 27.0 & 21.6 & 5.2 & 5.9 & 6.2 \\
\hline 6 & 18 & 57 & 41 & 0.34 & 27.8 & 24.3 & 27.7 & 1.7 & 2.5 & 1.4 & 11.1 & 8.6 & 10.8 & 27.5 & 44.9 & 32.7 & 4.4 & 5.6 & 3.6 \\
\hline 9 & 31 & 67 & 40 & 0.31 & 23.6 & 26.0 & 24.5 & 1.6 & 1.6 & 1.5 & 12.7 & 10.0 & 10.9 & 30.0 & 42.5 & 30.6 & 4.3 & 5.2 & 4.3 \\
\hline 10 & 31 & 64 & 37 & 0.30 & 23.7 & 23.1 & 20.5 & 1.3 & 1.5 & 0.9 & 10.7 & 10.5 & 9.2 & 30.3 & 23.8 & 23.2 & 5.0 & 6.1 & 5.8 \\
\hline 11 & 35 & 73 & 45 & 0.29 & 21.9 & 25.7 & 23.0 & 1.5 & 1.4 & 1.4 & 11.3 & 10.8 & 10.6 & 40.9 & 45.3 & 36.5 & 4.6 & 4.2 & 4.0 \\
\hline 12 & 43 & 87 & 56 & 0.27 & 22.5 & 23.7 & 22.1 & 1.2 & 1.0 & 0.9 & 12.5 & 10.9 & 11.3 & 44.8 & 42.8 & 50.9 & 4.4 & 4.7 & 4.0 \\
\hline 13 & 28 & 53 & 35 & 0.25 & 27.0 & 26.4 & 27.7 & 1.3 & 1.7 & 1.4 & 10.5 & 6.9 & 10.8 & 36.9 & 51.5 & 32.7 & 4.1 & 4.7 & 3.6 \\
\hline 14 & 77 & 47 & 76 & 0.24 & 20.6 & 20.3 & 20.9 & 1.2 & 1.5 & 1.0 & 9.0 & 10.4 & 9.3 & 43.6 & 45.3 & 49.8 & 4.3 & 4.4 & 5.3 \\
\hline 15 & 33 & 53 & 46 & 0.19 & 27.0 & 26.4 & 27.7 & 1.3 & 1.7 & 1.4 & 10.5 & 6.9 & 10.8 & 36.9 & 51.5 & 32.7 & 4.1 & 4.7 & 3.6 \\
\hline
\end{tabular}

${ }^{\mathrm{z}}$ The alternate bearing index $(I)$ was calculated using the following formula: $I=\frac{1}{(n-1)}\left[\frac{(a 2-a 1)}{(a 2+a 1)}+\frac{(a 3-a 2)}{(a 3+a 2)}+\ldots\right]$,

$n=$ number of seasons; $a$ = fruit yield (as kg/tree) in the corresponding seasons, with the difference in yield between two seasons expressed as an absolute value. 
Table 9. The effect of fruit load in 15 commercial 'Nadorcott' mandarin orchards on the concentration of leaf macronutrients.

\begin{tabular}{|c|c|c|c|c|c|}
\hline \multirow{2}{*}{$\begin{array}{l}\text { Orchard } \\
\text { fruiting status }{ }^{2}\end{array}$} & $\mathrm{~N}$ & $\mathrm{P}$ & $\mathrm{K}$ & $\mathrm{Ca}$ & $\mathrm{Mg}$ \\
\hline & \multicolumn{5}{|c|}{ (mg.g $\mathrm{g}^{-1}$ leaf dry weight) } \\
\hline $\begin{array}{l}\text { "Off" } \\
(<47 \mathrm{~kg} / \text { tree })\end{array}$ & 23.1 & 1.4 & $10.5 \mathrm{a}$ & $34.8 \mathrm{~b}$ & 4.9 \\
\hline $\begin{array}{l}\text { "On" } \\
(>47 \mathrm{~kg} / \text { tree })\end{array}$ & 22.6 & 1.4 & $9.4 \mathrm{~b}$ & $42.7 \mathrm{a}$ & 4.9 \\
\hline$P$ value & 0.18 & 0.65 & 0.04 & $<0.01$ & 0.39 \\
\hline
\end{tabular}

${ }^{\mathrm{z}}$ The median and mean values for fruit load of all commercial orchards were determined using descriptive statistics.

Different letters in the same column denote significant differences between values $(P<0.05$; Fisher's least significant difference test; $n=34$ ).

from research in other evergreen tree crops, e.g., olive (Jiménez-Moreno and FernándezEscobar, 2017). More significantly, the results presented herein are in agreement with results from research in other mandarin cultivars. In 'Satsuma' mandarin (Citrus unshiu), Mudau et al. (2004) demonstrated that despite a wide range in annual $\mathrm{N}$ application rates and varying methods of application, no different effects were recorded for fruit load or any other horticultural responses between any of the treatments. In 'Moncada' mandarin, it was shown that $\mathrm{N}$ is not a limiting factor for vegetative shoot development in alternate bearing trees (Martínez-Alcántara et al., 2015), and in 'Murcott' (Smith, 1976) and 'Nadorcott' mandarins (Stander et al., 2017), leaf N, P, and $\mathrm{K}$ concentrations and leaf $\mathrm{N}$ concentration in "off" trees were shown to be a result, not a cause, of alternate bearing. There may be a minimum level for each respective macronutrient required by a citrus tree to maintain metabolism and general physiological function, but all the orchards used as experimental sites in this study were well fertilized as reflected by the high macronutrient concentration in leaves. The trees were never subject to any nutrient deficiency that may have affected primary metabolism and contributed to alternate bearing in such a manner.

In this study, macronutrient concentrations in the leaf appeared not to have played a role in the perpetuation of alternate bearing in 'Nadorcott' mandarin trees, and adequate nutrient content did not alter the alternate bearing cycle. Alternate bearing occurred in 'Nadorcott' mandarin trees that were well fertilized. Alternative factors such as a hormonal regulation of vegetative shoot development, root growth, and flowering may be of more relevance to alternate bearing cycles (Goldberg-Moeller et al., 2013; Shalom et al., 2012, 2014; Ulger et al., 2004).

\section{Conclusions}

In this study, the concentration of macronutrients in leaves did not play a role in the perpetuation of alternate bearing in 'Nadorcott' mandarin trees. Fruit load affected the concentration of the macronutrients in leaves in some cases but not to the detriment of vegetative shoot development, flowering, or fruit load of the following season. The crop removal factor was higher for each macronutrient in "off" trees, but the harvest of an $\approx 8$-fold higher fruit load in "on" trees removed 1.5-7 times more macronutrients than the harvest of fruit in "off" trees. In "off" trees, N, P, and K, and in "on" trees, Ca accumulated in leaves in season 1 to between $20 \%$ and $30 \%$ higher concentrations, but the higher macronutrient status did not manifest in or consistently correlate with intensity of summer vegetative shoot development in the current season, flowering in the next season, or both - the two main determinants of fruit load in 'Nadorcott' mandarin. Apart from some anomalies, concentrations of macronutrients in leaves were unaffected by defruiting and foliar spray applications of $\mathrm{N}$ and $\mathrm{K}$ to "on" trees, and showed no consistent relationship with treatment effects on parameters of vegetative shoot flush, flowering, and fruit load. This study, therefore, does not support a role for leaf macronutrients in the regulation of vegetative shoot development, flowering, and fruit load in alternate bearing 'Nadorcott' mandarin trees. Changes in leaf macronutrient concentration in leaves can be considered a consequence of, rather than a cause of, differences in fruit load from one season to another.

\section{Literature Cited}

Alva, A.K., S. Paramasivam, A. Fares, T.A. Obreza, and A.W. Schuman. 2006. Nitrogen best management practice for citrus trees II. Nitrogen fate. Transport and components of $\mathrm{N}$ budget. Scientia Hort. 109:223-233.

Burger, W.T., A.P. Vincent, C.J. Barnard, J.A. du Plessis, and J.H.E. Smith. 1970. Metodes waarvolgens die grootte van sitrusbome bepaal kan word. SA. Citrus J. 433:13-15 (Afrikaans)

Campisi-Pinto, S., Y. Zheng, P.E. Rolshausen, D.E. Crowley, G. Bender, M. Bianchi, T. Khuong, and C.J. Lovatt. 2017. Optimal nutrient concentration ranges of 'Hass' avocado cauliflower stage inflorescences-Potential diagnostic tool to optimize tree nutrient status and increase yield. HortScience 52:1707-1715.

Castillo-Gonzalez, A.M., J.L. Tirado-Torres, M. Rubi-Arriga, and E. Avita-Garcia. 2000. Seasonal variation in nutrient concentration in leaves and inflorescences of avocado. J. Plant Nutr. 23:663-671.

Chapman, H.D. 1949. Citrus leaf analysis. Nutrient deficiencies, excess and fertilizer requirements of soil indicated by diagnostic aid. Calif. Agr. 3:10-14

Chapman, H.D. 1968. The mineral nutrition of citrus, p. 127-289. In: W. Reuther, H.J. Weber, and L.D. Bathelor (eds.). The citrus industry. Univ. California, Riverside, CA.

Du Plessis, S.F. 1977. Soil analysis as a necessary complement to leaf analysis for fertilizer advisory purposes. Proc. Intl. Soc. Citricult. 1:1519.

Du Plessis, S.F. and T.J. Koen. 1992. Leaf analysis norms for lemons [Citrus limon (L.) Burm.]. Proc. Intl. Soc. Citricult. 2:551-552.

Du Plessis, S.F., T.J. Koen, and W.J. Odendaal. 1992. Interpretation of Valencia leaf analysis by means of the N/K ratio approach. Proc. Intl. Soc. Citricult. 2:553-555.
Embleton, T.W., W.W. Jones, C. Pallares, and R.G. Platt. 1978. Effects of fertilization of citrus on fruit quality and ground water nitrate-pollution. Proc. Intl. Soc. Citricult. 280-285.

Embleton, T.W., H.J. Reitz, and W.W. Jones. 1973. Citrus fertilization, p. 122-181. In: W. Reuther (ed.). The citrus industry. Vol. 3. Univ. California Div. Agr. Sci., Berkeley, CA.

Galliani, S., S.P. Monselise, and R. Goren. 1975. Improving fruit size and breaking alternate bearing in 'Wilking' mandarins by ethephon and other agents. HortScience 10:68-69.

Goldberg-Moeller, R., L. Shalom, L. Shlizerman, S. Samuels, N. Zur, R. Ophir, E. Blumwald, and A. Sadka. 2013. Effects of gibberellin treatment during flowering induction period on global gene expression and the transcription of floweringcontrol genes in citrus buds. Plant Sci. 198:46-57.

Golomb, A. and E.E. Goldschmidt. 1987. Mineral nutrient balance and impairment of the nitratereducing system in alternate-bearing 'Wilking' mandarin trees. J. Amer. Soc. Hort. Sci. 112:397401.

Gur, A., R.M. Samish, and D. Zamet. 1969. A comparison of different planting distances for apple trees. Isr. J. Agr. Res. 19:79-86.

Hield, H.Z. and R.H. Hilgeman. 1969. Alternate bearing and chemical fruit thinning of certain citrus varieties. Proc. Intl. Soc. Citricult. 3:11451153.

Hou, X. and B.T. Jones. 2000. Inductively coupled plasma/optical emission spectrometry, p. 94689485. In: R.A. Meyers (ed.). Encyclopedia of analytical chemistry. Wiley, Chichester, UK.

Jiménez-Moreno, M.J. and R. Fernández-Escobar. 2017. Influence of nutritional status of phosphorous on flowering in the olive (Olea europaea L.). Scientia Hort. 223:1-4.

Jones, W.W. and T.W. Embleton. 1969. Development and current status of citrus leaf analysis as a guide to fertilization in California. Proc. Intl. Soc. Citricult. 3:1669-1671.

Jorgensen, K.R. and G.H. Price. 1978. The citrus leaf and soil analysis system in Queensland. Proc. Intl. Soc. Citricult. 297-299.

Khelil, M.B., M. Sanaa, M. Msallem, and A. Larbi. 2010. Floral analysis as a new approach to evaluate the nutritional status of olive trees. J. Plant Nutr. 33:627-639.

Koo, R.C.J., C.A. Anderson, D.V. Calvert, I. Stewart, D.P.H. Tucker, and H.K. Wutscher. 1984. Recommended fertilizers and nutritional sprays for citrus. Fla. Agr. Expt. Sta. Bul. 536D.

Koo, R.C.J. and J.W. Sites. 1956. Mineral composition of citrus leaves and fruit as associated with position on the tree. Proc. Amer. Soc. Hort. Sci. 68:245-252.

Lovatt, C.J. 1999. Timing citrus and avocado foliar nutrient applications to increase fruit set and size. HortTechnology 9:607-612.

Lovatt, C.J. 2013. Properly timing foliar-applied fertilizers increases efficacy: A review and update on timing foliar nutrient applications to citrus and avocado. HortTechnology 23:536-541.

Martínez-Alcántara, B., D.J. Iglesias, C. Reig, C. Mesejo, M. Agustí, and E. Primo-Millo. 2015. Carbon utilization by fruit limits shoot growth in alternate-bearing citrus trees. J. Plant Physiol. 176:108-117.

Martinez, H.E.P., R.B. Souza, J.A. Bayona, V.H. Alvarez Venegas, and M. Sanz. 2003. Coffee tree floral analysis as a means of nutritional diagnosis. J. Plant Nutr. 26:1467-1482.

Mirsoleimani, A., A-R. Shahsavar, and B. Kholdebarin. 2014. Seasonal changes of mineral nutrient concentrations of leaves and stems of 'Kinnow' mandarin trees in relation to alternate bearing. Intl. J. Fruit Sci. 14:117-132. 
Monselise, S.P. and E.E. Goldschmidt. 1982. Alternate bearing in fruit trees. Hort. Rev. 4:128-173.

Monselise, S.P., E.E. Goldschmidt, A. Golomb, and R. Rolf. 1983. Alternate bearing in citrus: Long-term effects of a single girdling treatment on individual 'Michal' tangerine branches. J. Amer. Soc. Hort. Sci. 108:373-376.

Moss, G.I., J. Bellamy, and K.B. Bevington. 1974. Controlling biennial bearing. Austral. Citrus News. 50:6-7.

Mudau, F.N., S. Tuwana, K.I. Theron, and E. Rabe. 2004. Effect of timing and method of nitrogen application on rind colour, fruit size, internal fruit quality and yield of 'Mihowase Satsuma' mandarin (Citrus unshiu Marc.). S. Afr. J. Plant Soil 21:90-93.

Neilsen, G.H., E.J. Hogue, and P. Parchomchuk. 1990. Flowering of apple trees in the second year is increased by first-year P fertilization. HortScience 25:1247-1250.

Quaggio, J.A., H. Cantarella, and D. Mattos, Jr. 1996. Soil testing and leaf analysis in BrazilRecent developments. Proc. Intl. Soc. Citricult. 8:1269-1275.

Raveh, E. 2013. Citrus leaf nutrient status: A critical evaluation of guidelines for optimal yield in Israel. Z. Pflanzenernähr. Bodenk. 176:420-428.

Razeto, B. and J. Salgado. 2004. The inflorescence and fruit peduncle as indicators of nitrogen status of the avocado tree. HortScience 39:11731174.

Rosecrance, R.C., S.A. Weinbaum, and P.H. Brown. 1998. Alternate bearing affects nitrogen, phosphorus, potassium and starch storage pools in mature pistachio trees. Ann. Bot. $82: 463-470$

Shalom, L., S. Samuels, N. Zur, L. Shlizerman, A. Doron-Faigenboim, E. Blumwald, and A. Sadka. 2014. Fruit load induces changes in global gene expression and in abscisic acid (ABA) and indole acetic acid (IAA) homeostasis in citrus buds. J. Expt. Bot. 65:3029-3044.

Shalom, L., S. Samuels, N. Zur, L. Shlizerman, H. Zemach, M. Weissberg, R. Ophir, E. Blumwald, and A. Sadka. 2012. Alternate bearing in citrus: Changes in the expression of flowering control genes and in global gene expression in ON- versus OFF-crop trees. PLoS One 7: e46930.

Smith, P.F. 1966. Leaf analysis of citrus. p. 208 228. In: N.F. Childers (ed.). Nutrition of fruit crops. Somerset Press Inc., Somerville, NJ.
Smith, P.F. 1976. Collapse of 'Murcott' tangerine trees. J. Amer. Soc. Hort. Sci. 101:23-25.

Stander, O.P.J., G.H. Barry, and P.J.R. Cronjé. 2017. Fruit-load-induced starch accumulation causes leaf chlorosis in 'Nadorcott' mandarin. Scientia Hort. 222:62-68.

Stander, O.P.J., G.H. Barry, and P.J.R. Cronjé. 2018. Fruit load limits root growth, summer vegetative shoot development and flowering in alternate bearing 'Nadorcott' mandarin trees. J. Amer. Soc. Hort. Sci. 143:213-225.

Stander, O.P.J. and P.J.R. Cronjé. 2016. Reviewing the commercial potential of hand thinning in citrus with a cost-benefit analysis of summer hand thinning of 'Nadorcott' mandarin. HortTechnology 26:206-212.

Ulger, S., S. Sonmez, M. Karkacier, N. Ertoy, and O. Akdesir. 2004. Determination of endogenous hormones, sugars and mineral nutrition levels during the induction, initiation and differentiation stage and their effects on flower formation in olive. Plant Growth Regulat. 42:89-95.

Verreynne, J.S. and C.J. Lovatt. 2009. The effect of crop load on bud break influences return bloom in alternate bearing 'Pixie' mandarin. J. Amer. Soc. Hort. Sci. 34:299-307. 